\title{
Front Matter: Volume 10196
}

, "Front Matter: Volume 10196," Proc. SPIE 10196, Sensors and Systems for Space Applications X, 1019601 (19 June 2017); doi: 10.1117/12.2281263

SPIE. Event: SPIE Defense + Security, 2017, Anaheim, CA, United States 


\title{
PROCEEDINGS OF SPIE
}

\section{Sensors and Systems for Space Applications $X$}

\author{
Khanh D. Pham \\ Genshe Chen \\ Editors
}

10-11 April 2017

Anaheim, California, United States

Sponsored and Published by

SPIE 
The papers in this volume were part of the technical conference cited on the cover and title page. Papers were selected and subject to review by the editors and conference program committee. Some conference presentations may not be available for publication. Additional papers and presentation recordings may be available online in the SPIE Digital Library at SPIEDigitallibrary.org.

The papers reflect the work and thoughts of the authors and are published herein as submitted. The publisher is not responsible for the validity of the information or for any outcomes resulting from reliance thereon.

Please use the following format to cite material from these proceedings:

Author(s), "Title of Paper," in Sensors and Systems for Space Applications $X$, edited by Khanh D. Pham, Genshe Chen, Proceedings of SPIE Vol. 10196 (SPIE, Bellingham, WA, 2017) Sevendigit Article CID Number.

ISSN: 0277-786X

ISSN: 1996-756X (electronic)

ISBN: 9781510608931

ISBN: 9781510608948 (electronic)

Published by

SPIE

P.O. Box 10, Bellingham, Washington 98227-0010 USA

Telephone +1 3606763290 (Pacific Time) · Fax +1 3606471445

SPIE.org

Copyright (c) 2017, Society of Photo-Optical Instrumentation Engineers.

Copying of material in this book for internal or personal use, or for the internal or personal use of specific clients, beyond the fair use provisions granted by the U.S. Copyright Law is authorized by SPIE subject to payment of copying fees. The Transactional Reporting Service base fee for this volume is $\$ 18.00$ per article (or portion thereof), which should be paid directly to the Copyright Clearance Center (CCC), 222 Rosewood Drive, Danvers, MA 01923. Payment may also be made electronically through CCC Online at copyright.com. Other copying for republication, resale, advertising or promotion, or any form of systematic or multiple reproduction of any material in this book is prohibited except with permission in writing from the publisher. The CCC fee code is 0277-786X/17/\$18.00.

Printed in the United States of America.

Publication of record for individual papers is online in the SPIE Digital Library.

\section{SPIE. DIGITAL \\ SPIEDigitalLibrary.org}

Paper Numbering: Proceedings of SPIE follow an e-First publication model. A unique citation identifier (CID) number is assigned to each article at the time of publication. Utilization of CIDs allows articles to be fully citable as soon as they are published online, and connects the same identifier to all online and print versions of the publication. SPIE uses a seven-digit CID article numbering system structured as follows:

- The first five digits correspond to the SPIE volume number.

- The last two digits indicate publication order within the volume using a Base 36 numbering system employing both numerals and letters. These two-number sets start with 00, 01, 02, 03, 04, 05, 06, 07, 08, 09, OA, OB ... 0Z, followed by 10-1Z, 20-2Z, etc. The CID Number appears on each page of the manuscript. 


\title{
Contents
}

\author{
$\checkmark$ Authors \\ vii Conference Committee \\ ix Introduction
}

\section{SESSION 1 ADVANCED CHARACTERIZATION OF SPACE ENVIRONMENTAL VARIABLES FOR SPACE} SITUATIONAL AWARENESS

1019602 Detecting faint nearby companions to geostationary satellites with optical interferometry (Invited Paper) [10196-1]

1019603 Irradiation effect on back-gate graphene field-effect transistor [10196-2]

1019604 The analysis of the defects of the view field of the UV image intensifier [10196-3]

1019605 Research on the new type of multi-functional satellite system for space debris detection [10196-4]

1019606 On-orbit degradation of recent space-based solar instruments and understanding of the degradation processes [10196-5]

1019607 Big data for space situation awareness [10196-6]

\section{SESSION 2 ACQUISITION WARGAMING FOR FUTURE SPACE SYSTEMS}

1019608 Owning the program technical baseline for future space systems acquisition: program technical baseline tracking tool (Invited Paper)[10196-7]

1019609 War-gaming application for future space systems acquisition: MATLAB implementation of war-gaming acquisition models and simulation results (Invited Paper) [10196-8]

$101960 \mathrm{~A}$ War-gaming application for future space systems acquisition part 1: program and technical baseline war-gaming modeling and simulation approaches (Invited paper) [10196-9]

10196 OB War-gaming application for future space systems acquisition part 2: acquisition and bidding war-gaming modeling and simulation approaches for FFP and FPIF (Invited Paper) [10196-10] 
10196 OC Cooperative angle-only orbit initialization via fusion of admissible areas [10196-11]

10196 OD An orbital emulator for pursuit-evasion game theoretic sensor management [10196-12]

10196 OE Joint sparsity based heterogeneous data-level fusion for target detection and estimation [10196-13]

10196 OF An adaptive software defined radio design based on a standard space telecommunication radio system API [10196-14]

$101960 G \quad$ Machine learning based Intelligent cognitive network using fog computing [10196-15]

SESSION 4 ADDITIVE MANUFACTURING FOR SPACE ACCESS

$10196 \mathrm{OH}$ An update on the OpenOrbiter I Mission and its paradigm's benefits for the defense, homeland security and intelligence communities [10196-16]

10196 Ol Consideration of materials for creating 3D printed space sensors and systems [10196-17]

\section{SESSION $5 \quad$ SMALL SATELLITE DESIGN AND DEVELOPMENT}

10196 0J Electrical design for origami solar panels and a small spacecraft test mission [10196-19]

10196 OK Low-cost satellite mechanical design and construction [10196-20]

$101960 \mathrm{M}$ CubeSat mechanical design: creating low mass and durable structures [10196-22] 


\section{Authors}

Numbers in the index correspond to the last two digits of the seven-digit citation identifier (CID) article numbering system used in Proceedings of SPIE. The first five digits reflect the volume number. Base 36 numbering is employed for the last two digits and indicates the order of articles within the volume. Numbers start with 00, 01, 02, 03, 04, 05, 06, 07, 08, 09, OA, OB...0Z, followed by 10-12, 20-2Z, etc.

Armstrong, J. Thomas, 02

Baines, Ellyn K., 02

Barcomb, Heather, 09

Bekki, S., 06

BenMoussa, A., 06

Black, William A., 09

Blasch, Erik, 07, OC, OD, OE, OF, OG

Boisjolie-Gair, Nathaniel, OK

Bolsée, D., 06

Chen, Genshe, OC, OD, OE, OF, OG

Chen, Xinlu, 03

Coons, Amanda, 09

Damé, L., 06

Dammasch, I. E., 06

Distasio, Marcello, OE

Dominique, M., 06

Drewelow, James, 0J

Fiedler, Gilbert, OM

Fu, Qiang, 05

Fu, RongGuo, 04

Guillen, Andy T., 08, 09, 0A, OB

Guo, Linghua, 05

Hant, James J., 08

Hauchecorne, A., 06

Jia, Bin, OC, OD

Jiang, Huilin, 05

Kizer, Justin R., 08, 09

Li, Lun, OG

LU, Jingyang, OG

Marshall, Karel, 09

Mayberry, Clay, 03

Meftah, M., 06

Min, Inki A., 08

Nguyen, Tien M., 08, 09, OA, OB

Niu, Ruixin, OE

Pereira, N., 06

Pham, Khanh, OC, OD, OF, OG

Pugh, Mark, 07

Raquepas, Joe, 07

Reimers, Jacob, 0 l

Restaino, Sergio R., 02

Rocci, Peter, 07

Rogers, Blake A., 09

Schmitt, Henrique R., 02

Sharma, Ashwani K., 03

Sheaff, Carolyn, 07

Shen, Dan, OC, OD, OE, OG

Siedlak, Dennis J. L., 08

Srivastava, Ashok, 03
Straub, Jeremy, $\mathrm{OH}, \mathrm{OI}, \mathrm{OJ}, \mathrm{OK}, \mathrm{OM}$

Tian, Xin, OF

Tran, Hien T., 09

Vienhage, Paul, 09

Wang, Gang, OD

Wang, GuiYuan, 04

Wang, Tao, OD

Wang, Zhonghai, OC, OD

Wei, YiFang, 04

Xiong, Wenhao, OF

$\mathrm{Xu}, \mathrm{Xihe}, 05$

Yang, Qi, 04

Yang, $\mathrm{Xu}, 04$

Yoh, James, 08, 09

Zulch, Peter, $\mathrm{OE}$ 
Proc. of SPIE Vol. 10196 1019601-6

Downloaded From: https://www.spiedigitallibrary.org/conference-proceedings-of-spie on 26 Apr 2023 Terms of Use: https://www.spiedigitallibrary.org/terms-of-use 


\section{Conference Committee}

Symposium Chair

Donald A. Reago Jr., U.S. Army Night Vision \& Electronic Sensors

Directorate (United States)

Symposium Co-chair

Arthur A. Morrish, Raytheon Space and Airborne Systems (United States)

Conference Chairs

Khanh D. Pham, Air Force Research Laboratory (United States)

Genshe Chen, Intelligent Fusion Technology, Inc. (United States)

Conference Program Committee

Trevor J. Bihl, Air Force Institute of Technology (United States)

Erik P. Blasch, Air Force Research Laboratory (United States)

Yu Chen, Binghamton University (United States)

Joseph L. Cox, Missile Defense Agency (United States)

Sarah T. Crites, University of Hawai'i (United States)

Thomas George, SaraniaSat Inc. (United States)

Ping Hagler, Missile Defense Agency (United States)

Richard T. Howard, NASA Marshall Space Flight Center (United States)

Uttam Kumar Majumder, Air Force Research Laboratory

(United States)

Brian K. McComas, Raytheon Missile Systems (United States)

Jeremy Murray-Krezan, Air Force Research Laboratory (United States)

Tien M. Nguyen, The Aerospace Corporation (United States)

Andre Samberg, Sec-Control Finland Ltd. (Finland)

Dan Shen, Intelligent Fusion Technology, Inc. (United States)

Robert SiVilli, Air Force Research Laboratory (United States)

Ryan M. Weisman, Air Force Research Laboratory (United States)

Henry Zmuda, University of Florida (United States)

Session Chairs

1 Advanced Characterization of Space Environmental Variables for Space Situational Awareness

Brian K. McComas, Raytheon Missile Systems (United States)

Henrique R. Schmitt, U.S. Naval Research Laboratory (United States) 
2 Acquisition Wargaming for Future Space Systems

Dan Shen, Intelligent Fusion Technology, Inc. (United States)

Wenhao Xiong, Intelligent Fusion Technology, Inc. (United States)

3 Data Analytics and Decision Support for Space C2 and Satellite Operations

Bin Jia, Intelligent Fusion Technology, Inc. (United States)

Ruixin Niu, Virginia Commonwealth University (United States)

4 Additive Manufacturing for Space Access

Jeremy Straub, North Dakota State University (United States)

Jacob Reimers, North Dakota State University (United States)

5 Small Satellite Design and Development

Jeremy Straub, North Dakota State University (United States) 


\section{Introduction}

Our thoughts lately are on what decision support science has done to improve the qualities of space activities for knowledge discovery, economic prosperity, and national security. Along these lines, and appropriately for the conference, we are wondering what particular "emerging" decision support frameworks and processes can affect the wish list of civil and military space systems. Lo and behold, we have run across some possible technical approaches. We thank guest speaker Dr. Tien Nguyen from Aerospace Corporation for his enthusiastic efforts in organizing the feature presentations for this conference on Sensors and Systems for Space Applications X. His invited talks, "War-Gaming Application for Future Space Systems Acquisition Part 1: Program and Technical Baseline War-Gaming Modeling Approach" and "War-Gaming Application for Future Space Systems Acquisition: MATLAB Implementation of War-Gaming Acquisition Models and Simulation Results," provided merits to foster multidisciplinary discussions that enable participants to gain an understanding of the multi-team competitive decision making issues, and suggested creative acquisition strategies that would achieve: i) affordability and flexibility; ii) acquisition time reduction; and iii) meeting space operator and user needs. So there you have it: war-gaming for emerging science and technologies will seamlessly integrate government and commercial assets into a cloud environment of program and technical baselines to enhance solution competition and cost affordability.

This year, the technical program committee has organized five technical sessions, considering all the aspects of: 1) Advanced Characterization of Space Environmental Variables for Space Situational Awareness; 2) Acquisition Wargaming for Future Space Systems; 3) Data Analytics and Decision Support for Space C2 and Satellite Operations; 4) Additive Manufacturing for Space Access; and 5) Small Satellite Design and Development. Such forums attracted the interest of government agencies, academia and industry partners.

We had the pleasure of acknowledging the authors for choosing this avenue for publication of their technical contributions that result in quality work published on the SPIE Digital Library. A very special thank you is in order for the members of our program committee and the session chairs for their tireless support making this conference another success. Many thanks are also due to SPIE staff for their invaluable help in making this all possible.

We really need new members and volunteers for the program committee, and we really do want to hear what you have to say. This includes getting help and hearing from you in technical matters as well as in other matters ranging from the way this conference is run to the presentation in this Proceeding Volume. The program committee and volunteers have got us this far, and continue to make us move forward as a comprehensive entity. 
Looking ahead to 2018, we wish success to our new committee members. Many thanks for your continued interest to you, our readers.

Khanh D. Pham

Genshe Chen

Proc. of SPIE Vol. 10196 1019601-10

Downloaded From: https://www.spiedigitallibrary.org/conference-proceedings-of-spie on 26 Apr 2023 Terms of Use: https://www.spiedigitallibrary.org/terms-of-use 